\title{
Zmiany w sercu po przeszczepieniu płuc z powodu włóknienia z towarzyszącym nadciśnieniem płucnym
}

\author{
Heart transformation after lung transplantation due to lung fibrosis \\ with concomitant pulmonary hypertension
}

\author{
Anna Maria Kubisa ${ }^{1}$, Bartosz Karol Kubisa ${ }^{2}$, Tomasz Paweł Grodzki ${ }^{2}$, \\ Maria Piotrowska ${ }^{2}$, Małgorzata Peregud-Pogorzelska ${ }^{3}$ \\ ${ }^{1}$ Oddział Chorób Wewnętrznych Samodzielnego Publicznego Wojewódzkiego Szpitala Zespolonego w Szczecinie-Zdunowie \\ ${ }^{2}$ Klinika Chirurgii Klatki Piersiowej i Transplantacji Pomorskiego Uniwersytetu Medycznego w Szczecinie \\ ${ }^{3}$ Klinika Kardiologii, Samodzielny Publiczny Szpital Kliniczny nr 2, Pomorski Uniwersytet Medyczny w Szczecinie
}

\section{Streszczenie}

Echokardiografia w nadciśnieniu płucnym $(\mathrm{PH})$ towarzyszącym chorobom płuc jest podstawowym, nieinwazyjnym narzędziem diagnostycznym, służącym do oceny występowania prawdopodobieństwa PH. Jego obecność jest jednym z kryteriów kwalifikujących do przeszczepienia płuc (LuTx) oraz decyduje, czy konieczne będzie użycie pozaustrojowej oksygenacji krwi w trakcie LuTx. Przedstawiony przypadek ukazuje szybkość zmian dokonujących się w strukturach i czynności prawego serca u chorego po LuTx.

Słowa kluczowe: włóknienie płuc, przeszczepienie płuc, echokardiografia, wtórne nadciśnienie płucne

Folia Cardiologica 2018; 13, 1: 59-63

\section{Wstęp}

Transplantacja płuc jest zabiegiem operacyjnym przeprowadzanym u pacjentów ze schyłkowymi schorzeniami płuc prowadzącymi do niewydolności oddechowej, gdzie mimo optymalnego leczenia zachowawczego nie uzyskuje się poprawy, a przewidywany okres przeżycia nie przekracza 2 lat. Głównymi wskazaniami do przeszczepienia płuc (LuTx, lung transplantation) jest przewlekła obturacyjna choroba płuc (COPD, chronic obstructive pulmonary disease), idiopatyczne włóknienie płuc (IPF, idiopatic pulmonary fibrosis), choroba naczyń płucnych, w tym pierwotne nadciśnienie płucne (IPH, idiopatic pulmonary hypertension) [1, 2]. Dla pacjentów z IPF kryterium kwalifikującym do tego rodzaju zabiegu jest natężona pojemność życiowa poniżej 80\% (FVC, forced vital capacity) lub pojemność dyfuzyjna dla tlenku węgla poniżej 40\% (DLCO, diffusing capacity for carbon monoxide) z towarzyszącą hipoksją poniżej $60 \mathrm{~mm} \mathrm{Hg}$ krwi tętniczej [2]. Idiopatyczne włóknienie płuc jest najczęstszą (47-64\%) postacią śródmiąższowego zapalenia płuc. Średni wiek chorych w chwili rozpoznania IPF wynosi 66 lat. Etiologia tej choroby jest nieznana. Czynnikami ryzyka są: płeć męska (w 70\% chorują mężczyźni), palenie tytoniu powyżej 20 lat, refluks żołądkowo-przełykowy i zanieczyszczenie środowiska. Co roku diagnozuje się w Europie około 25 tys. nowych zachorowań na IPF. Średnia przeżycia wynosi 2-5 lat, tylko 37\% chorych przeżywa 5 lat.

\section{Opis przypadku}

W pracy przedstawiono przypadek mężczyzny w wieku 59 lat, z rozpoznanym w 2010 roku IPF. Chory nie palił 
tytoniu. Dominującymi objawami były u niego: pogłębiające się zmniejszenie tolerancji wysiłku i suchy kaszel. Od stycznia 2014 roku następowało pogorszenie samopoczucia; wystąpiły duszność spoczynkowa i zmniejszenie masy ciała o 16 kg. Przedmiotowo słyszalne były przypodstawne trzeszczenia i tachypnoe (32/min). Do leczenia włączono steroidy w dawce $40 \mathrm{mg} /$ dobę, uzyskując poprawę. Na podstawie wykonanej spirometrii i pletyzmografii stwierdzono: obniżenie natężonej objętości wydechowej pierwszosekundowej (FEV1, forced expiratory volume in 1 second) (styczeń-czerwiec 2014 r.) z 62 do $46 \%$ N oraz FVC z 60 do 53\%N. Pojemność dyfuzyjna dla tlenku węgla w tym samym okresie obniżyła się z 40 do $21 \%$. W tomografii komputerowej o wysokiej rozdzielczości (HRCT, high resolution computed tomography) obserwowano progresję zmian o charakterze włóknienia, tak zwane zmiany „plastra miodu”. W leczeniu utrzymano steroidy w dawce dobowej $40 \mathrm{mg}$ i domową tlenoterapie - 1,5-3 l/min. W echokardiografii (ECHO) wykazano: wielkość prawej komory (RV, right ventricle) w projekcji przymostkowej długiej (LAX, long-axis view) $28 \mathrm{~mm}$, poszerzony pień płucny $30 \mathrm{~mm}$, czas akceleracji (AcT, acceleration time) - 67 ms. Z powodu złych warunków badania nie oceniono gradientu niedomykalności zastawki trójdzielnej (TRV, tricuspid regurgitation peak velocity). Pacjent skierowany został do kliniki chirurgii klatki piersiowej i transplantacji w celu kwalifikacji do LuTx. W 6-minutowym teście chodu (6-MWT, 6 Minute Walk Test) (wrzesień 2014 r.) spoczynkowa saturacja krwi obwodowej wynosiła 90\%, badanie przerwano z powodu spadku saturacji wraz z trwaniem wysiłku kolejno: 83-82-85-84-78-77\%. W scyntygrafii perfuzyjnej płuc uwidoczniono znacznie obniżoną perfuzje prawego płuca - po przebytej zatorowości płucnej. W lewym płucu perfuzja była prawidłowa. Na podstawie wyników morfologii wykazano: poliglobulię, stężenie hemoglobiny $(\mathrm{Hb})-18,8 \mathrm{~g} / \mathrm{dl}$, hematokryt (HCT, hematocrit) - 55\%, liczbę krwinek czerwonych (RBC, red blood cells) $-5,8 \mathrm{mln} / \mu \mathrm{l}$. Wykonano łącznie trzy krwioupusty. Pacjenta zakwalifikowano do zabiegu LuTx z zaleceniem przewlekłego przyjmowania enoksaparyny 80 mg podskórnie. Ze względu na objawy prawokomorowej niewydolności serca - powiększenie wątroby oraz obrzęki kończyn dolnych - włączono leki moczopędne (furosemid $40 \mathrm{mg} / \mathrm{d}$., spironolakton $25 \mathrm{mg} / \mathrm{d}$.).W koronarografii nie wykazano zmian w naczyniach wieńcowych.

Badanie ECHO wykonane 3 miesiące przed przeszczepieniem uwidoczniło cechy świadczące o wysokim prawdopodobieństwie nadciśnienia płucnego (tab. 1, ryc. 1, 2). Przed zabiegiem LuTx stwierdzono bardzo wysokie wartości ciśnienia w prawej komorze zarówno w badaniu ECHO przezklatkowym, jak i w cewnikowaniu serca (ciśnienie skurczowe w prawej komorze [RVSP, right ventricular systolic pressure] $120 \mathrm{~mm} \mathrm{Hg}$ - pomiar wykonany cewnikiem Swana-Ganza w trakcie znieczulenia do zabiegu), z istotnym powiększeniem jam prawego serca (w LAX 38 mm, w projekcji czterojamowej 4C $48 \mathrm{~mm}$ ), amplitudą ruchu pierścienia trójdzielnego (TAPSE, tricuspid annular plane systolic excursion) wynoszącą $14 \mathrm{~mm}$, nieprawidłowym ruchem przegrody międzykomorowej na skutek przeciążenia ciśnieniowego RV, poszerzeniem pnia tętnicy płucnej do $36 \mathrm{~mm}$, z przepływem płucnym ze skróceniem AcT do 49 ms, z typowym zazębieniem śródskurczowym w badaniu Dopplera metodą fali pulsacyjnej.

28 października 2014 roku wykonano zabieg transplantacji obu płuc pobranych od zmarłego dawcy. Operację przeprowadzono ze wspomaganiem centralnej pozaustrojowej oksygenacji krwi (ECM0, extracorporeal membrane oxygenation) żylno-tętniczej, ponieważ podczas sekwencyjnego przeszczepiania płuc u pacjentów z towarzyszącym nadciśnieniem płucnym ECMO pełni rolę odciążająca płuca i serce, a szczególnie RV, chroni tym samym przed wystąpieniem ostrej niewydolności prawej komory. W kontrolnym ECHO serca, wykonanym w 2. dobie po zabiegu

Tabela 1. Porównanie parametrów echokardiografii w trzech punktach czasowych

\begin{tabular}{lccc} 
Parametr & \multicolumn{1}{c}{ Data pomiaru } \\
& $\begin{array}{c}\text { 25.06.2014 } \\
\text { 4 mies. przed LuTx }\end{array}$ & $\begin{array}{c}11.09 .2014 \\
\text { 6 tyg. przed LuTx }\end{array}$ & $\begin{array}{c}31.10 .2014 \\
\text { 2. doba po LuTx }\end{array}$ \\
Wymiar prawej komory w LAX [mm] & 30 & 38 & 32 \\
TAPSE [mm] & 16 & 14 & 19 \\
TRPG [mm Hg] & 52 & 105 & 25 \\
RVSP [mm Hg] & 62 & 120 & 35 \\
Szerokość pnia tętnicy płucnej [mm] & 28 & 36 & 30 \\
AcT [ms] & 48 & 49 & 115 \\
Powierzchnia prawego przedsionka $\left[\mathrm{cm}^{2}\right]$ & 18 & 24 & 19
\end{tabular}

LuTx (lung transplantation) - przeszczepienie płuc; LAX (Iong-axis view) - projekcja przymostkowa długa; TAPSE (tricuspid annular plane systolic excursion) - amplituda ruchu pierścienia trójdzielnego; TRPG (tricuspid regurgitation peak gradient) - gradient przez zastawkę trójdzielną RVSP (right ventricular systolic pressure) - ciśnienie skurczowe w prawej komorze; AcT (acceleration time) - czas akceleracji 


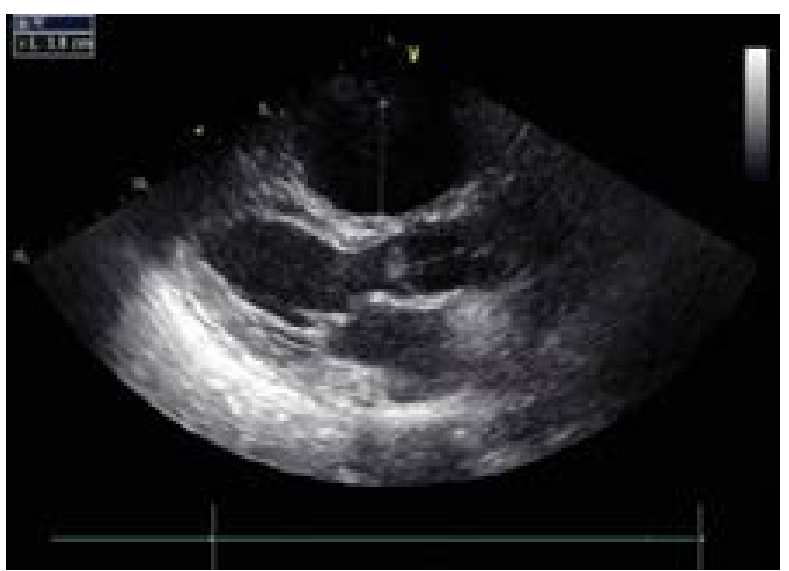

Rycina 1. Badanie echokardiograficzne w projekcji przymostkowej długiej (LAX, long-axis view) wykonane 6 tygodni przed przeszczepieniem płucu

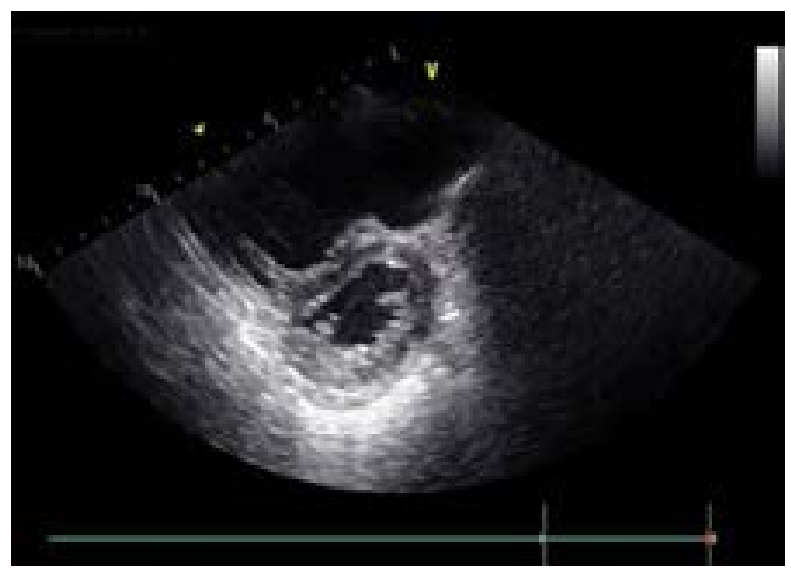

Rycina 2. Badanie echokardiograficzne w projekcji przymostkowej krótkiej (SAX, short axis), badanie wykonane 6 tygodni przed przeszczepieniem płucu

obserwowano stopniowe zmniejszanie się wielkości RV i prawego przedsionka (RA, right atrium) (z 24 do $19 \mathrm{~cm}^{2}$ ), poprawę funkcji RV (zwiększenie TAPSE z 14 do $19 \mathrm{~mm}$ ) z normalizacją gradientu przez zastawkę trójdzielną i ciśnienia w prawej komorze (tab. 1 , ryc. 3).

Chory wypisany do domu 20 grudnia 2017 roku. Systematycznie zgłasza się do Poradni Transplantacyjnej, parametry spirometryczne i DLCO utrzymują się na stałym, stabilnym poziomie. W 6-MWT dystans wynosi $600 \mathrm{~m}$, saturacja - 95-96\%, HR - 64-86/min. Po wypisaniu ze szpitala w wykonanym kontrolnym badaniu ECHO obraz przedstawiał się jak w październiku 2014 roku. Klinicznie nie stwierdzono cech niewydolności serca.

\section{Dyskusja}

Nadciśnienie płucne (PH, pulmonary hypertension) rozpoznaje się, jeśli średnie ciśnienie w tętnicy płucnej (mPAP, mean pulmonary arterial pressure) oznaczone podczas cewnikowania prawego serca jest równe lub przekracza $25 \mathrm{~mm} \mathrm{Hg}[3,4]$. Prezentowany przypadek dotyczy pacjenta, u którego PH rozwinęło się w przebiegu choroby miąższu płucnego (grupa 3 wg European Society of Cardiology [ESC]).

Jednym z pierwszych czynników PH w chorobach płuc jest skurcz tętniczek w płucnym łożysku naczyniowym spowodowany hipoksemią w pęcherzykach płucnych. Innymi czynnikami powodującymi PH jest ogólny proces zapalny, zaburzenia czynności komórek śródbłonka i niewłaściwy wzrost naczyń włosowatych. Zależna od hipoksemii wtórna czerwienica powoduje zwiększenie lepkości krwi, co utrudnia przepływ i dodatkowo obciąża prawą komorę. Wysokie PH może występować już we wczesnym okresie choroby. Dochodzi do angiopatii proliferacyjnej obejmującej błonę wewnętrzną i warstwę mięśniową w małych i średnich tętniczkach. Podobne zmiany w 30-60\% obejmują również żyły płucne. Nadciśnienie płucne może tym samym wynikać z upośledzenia drożności naczyń płucnych w przebiegu zmian zakrzepowo-zatorowych, ponieważ zatorowość w tej grupie występuje częściej i jest przyczyną 3\% zgonów.

Cewnikowanie serca jest niezbędne przy podejrzeniu wspótistnienia IPH lub nadciśnienia płucnego w przebiegu przewlekłej choroby zakrzepowo-zatorowej (CTEPH, chronic thromboembolic pulmonary hypertension), gdy ECHO serca jest niediagnostyczne [5]. W naszej klinice na początku działania programu przeszczepiania płuc wykonywano cewnikowanie prawego serca każdemu kandydatowi do LuTx. Wszystkie wyniki były wysoce zbieżne z wynikami ECHO przezklatkowego - różnice nie przekraczały $5-10 \mathrm{~mm} \mathrm{Hg}$, dlatego obecnie polegamy wyłącznie na tym badaniu. Cewnikowanie wykonuje się tylko w przypadkach wątpliwych, przy podejrzeniu współistnienia innych przyczyn PH. Wyższość cewnikowania prawego serca nad ECHO polega na tym, że umożliwia przeprowadzenie pomiaru ciśnienia zaklinowania (PCWP, pulmonary capillary wedge pressure), które wskazuje, czy niewydolność lewokomorowa nie jest komponentą $\mathrm{PH}$. Obecnie nie ma swoistego leczenia PH w przebiegu IPF. W przypadku hipoksemii stosuje się tlenoterapię, rehabilitacje oddechową oraz zoptymalizowaną terapię podstawowa. Wobec braku skutecznego leczenia zachowawczego pacjenci, u których rozpoznano IPF, powinni być jak najszybciej kwalifikowani do LuTx, które stanowi jedyną, skuteczną metodę leczenia i wpływa korzystnie na zmiany w sercu.

\section{Podsumowanie}

Przewlekłe choroby miąższu płuc prowadzą często do powstania wtórnego $\mathrm{PH}$, które świadczy o wyczerpaniu możliwości adaptacji organizmu do wzrastających oporów 

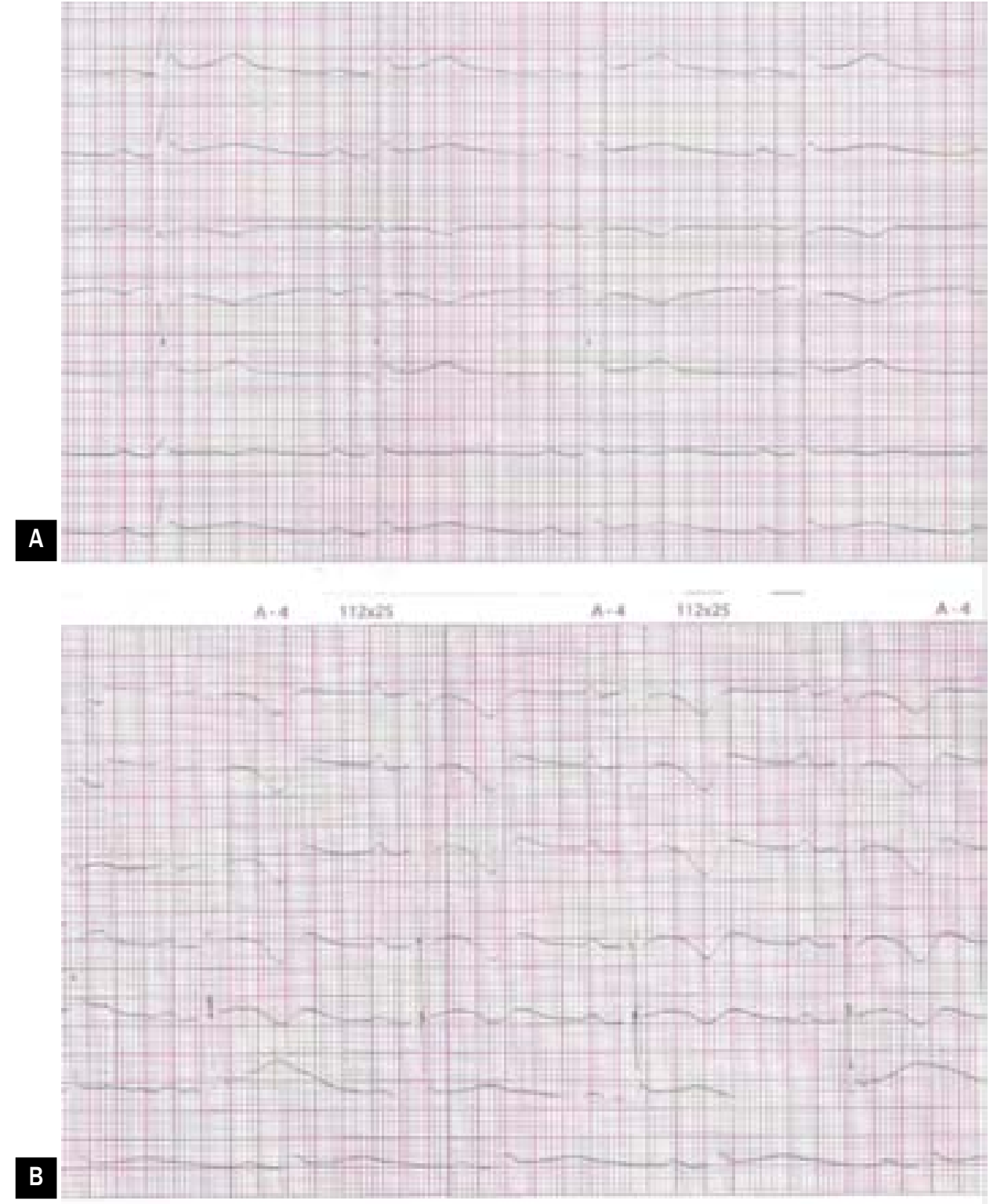

Rycina 3A, B. Zapis elektrograficzny chorego przed przeszczepieniem płuc

w łożysku płucnym. Leczenie zachowawcze ma ograniczone możliwości. Dlatego jedyną skuteczną metodą leczenia jest przeszczepienie płuc.

\section{Konflikt interesów}

Autorzy nie zgłaszają konfliktu interesów.

\section{Abstract}

Chronic lung tissue disease leads to secondary pulmonary hypertension (PH). The conservative treatment has limited possibilities and lung transplantation (LuTx) remains the final treatment solution. This case report presents the natural course of diagnostics and treatment of the patient with idiopatic pulmonary fibrosis and secondary $\mathrm{PH}$, who underwent LuTx.

Key words: lung fibrosis, lung transplantation, echocardiography, secondary pulmonary hypertension

Folia Cardiologica 2018; 13, 1: 59-63 


\section{Piśmiennictwo}

1. Rudski LG, Lai WW, Afilalo J, et al. Guidelines for the echocardiographic assessment of the right heart in adults: a report from the American Society of Echocardiography endorsed by the European Association of Echocardiography, a registered branch of the European Society of Cardiology, and the Canadian Society of Echocardiography. J Am Soc Echocardiogr. 2010; 23(7): 685-713; quiz 786, doi: 10.1016/j. echo.2010.05.010, indexed in Pubmed: 20620859.

2. Weill D, Benden C, Corris PA, et al. A consensus document for the selection of lung transplant candidates: 2014--an update from the Pulmonary Transplantation Council of the International Society for Heart and Lung Transplantation. J Heart Lung Transplant. 2015; 34(1): 1-15, doi: 10.1016/j.healun.2014.06.014, indexed in Pubmed: 25085497.
3. Lang RM, Badano LP, Mor-Avi V. Recommendations for cardiac chamber quantification by echocardiography in adults: an update from the American Society of Echocardiography and the European Association of Cardiovascular Imaging. Eur Heart J Cardiovasc Imaging. 2015; 16(3):233-70. (3): 233-270, doi: 10.1093/ehjci/jev014, indexed in Pubmed: 25712077.

4. Cottini S, Benden C, Huber LC, et al. Echocardiography accurately predicts pulmonary hypertension in patients with advanced lung disease. Crit Care. 2017; 21(1): 115, doi: 10.1186/s13054-017-1697-y, indexed in Pubmed: 28545472.

5. Denton CP, Cailes JB, Phillips GD, et al. Comparison of Doppler echocardiography and right heart catheterization to assess pulmonary hypertension in systemic sclerosis. Br J Rheumatol. 1997; 36(2): 239-243, indexed in Pubmed: 9133938. 